Short Communication

\title{
Electrochemical Impedance Spectroscopy Investigation of a Polyurethane Coating on Bridge 16Mnq Steel Surface
}

\author{
Xiaoqiang Xue and Junfu Lu* \\ State Key Laboratory of Geohazard Prevention and Geoenvironment Protection, Chengdu University \\ of Technology, Chengdu, Sichuan, 610059, P.R. China \\ *E-mail: junfulucut@163.com
}

doi: $10.20964 / 2017.04 .19$

Received: 28 December 2016 / Accepted: 11 February 2017 / Published: 12 March 2017

\begin{abstract}
The bridge 16Mnq steel sample was successfully coated with polyurethane film in order to enhance its corrosion resistance. The electrochemical properties of polyurethane film coated samples with different coating thicknesses $(60,80$ and $100 \mu \mathrm{m})$ were investigated using electrochemical impedance spectroscopy (EIS). Corrosion tests were carried out by exposing the coated system to $\mathrm{NaCl}$ aqueous solution with the concentration of $3.0 \%$ in a horizontal flat-cell. The improvement of corrosion resistance of the coated substrate was evaluated by the time dependent impedance parameters. The degradation phenomenon demonstrated by EIS measurements was related with the changes of mechanical properties of coated metals which could be measured by tests of microhardness and pulloff adhesion. Polyurethane coating was affirmed to possess strong adhesion and enhanced anticorrosion protection characteristics.
\end{abstract}

Keywords: Electrochemical impedance spectroscopy; Corrosion; Polyurethane; Pull-off adhesion; Microhardness

\section{FULL TEXT}

(C) 2017 The Authors. Published by ESG (www.electrochemsci.org). This article is an open access article distributed under the terms and conditions of the Creative Commons Attribution license (http://creativecommons.org/licenses/by/4.0/). 